\title{
PENGARUH PEMBELAJARAN MATA KULIAH KEWIRAUSAHAAN DAN PRAKTIK KEWIRAUSAHAAN TERHADAP MINAT BERWIRAUSAHA MAHASISWA FAKULTAS KEGURUAN DAN ILMU PENDIDIKAN UNIVERSITAS HKBP NOMMENSEN MEDAN
}

\author{
Dearlina Sinaga \\ Maya Andriani \\ Sihartono Sibagariang \\ Program Studi Pendidikan Ekonomi, Universitas HKBP Nommensen Medan \\ Email:mayaandriani6@gmail.com
}

\begin{abstract}
Abstrak
Penelitian ini bertujuan untuk mengetahui: (1) Pengaruh Pembelajaran Mata Kuliah Kewirausahaan terhadap Minat Berwirausaha Mahasiswa FKIP Universitas HKBP Nommensen Medan Tahun Pelajaran 2018/2019; (2) Pengaruh Praktik Kewirausahaan terhadap Minat Berwirausaha mahasiswa FKIP Universitas HKBP Nommensen Medan Tahun Pelajaran 2018/2019; (3) Pengaruh Pembelajaran Mata Kuliah Kewirausahaan dan Praktik Kewirausahaan secara bersama-sama terhadap Minat Berwirausaha Mahasiswa FKIP Universitas HKBP Nommensen Medan Tahun Pelajaran 2018/2019. Penelitian kuantitatif ini menggunakan sampel mahasiswa FKIP Universitas HKBP Nommensen Tahun Pelajaran 2018/2019 yang berjumlah 195 mahasiswa. Pengumpulan data pembelajaran mata kuliah kewirausahaan, praktik kewirausahaan dan minat berwirausaha menggunakan angket. Teknik analisa data yang digunakan yaitu teknik analisis regresi sederhana dan teknik analisis berganda.. Berdasarkan Hasil penelitian diperoleh kesimpulan pembelajaran mata kuliah kewirausahaan dan praktik kewirausahaan berpengaruh terhadap minat berwirausaha mahasiswa FKIP Universitas HKBP Nommensen Medan Tahun Pelajaran 2018/2019 baik secara parsial maupun simultan. koefisien determinasi sebesar 38,8\% dimana minat berwirausaha dipengaruhi oleh pembelajaran mata kuliah kewirausahaan dan praktik kewirausahaan sedangkan sisanya sebesar $61,2 \%$ dipengaruhi variable lain yang tidak diteliti dalam penelitian ini. Persamaan regresi ganda $Y=13,240+0,855 \cdot X_{1}+0,300 \cdot X_{2}$
\end{abstract}

Kata Kunci : Pembelajaran Mata Kuliah Kewirausahaan, Praktik Kewirausahaan, Minat Berwirausaha, Kewirausahaan,

\section{PENDAHULUAN}

Tantangan yang dihadapi dalam pembangunan suatu negara adalah mengatasi masalah pengangguran. Angka pengangguran menjadi salah satu prioritas pemerintah untuk diberi perhatian. Dalam Rencana Kerja Pemerintah (RKP) 2018, target pengangguran sekitar 5-5,3 persen. Menteri Perencanaan Pembangunan Nasional Bambang Brodjonegoro mengatakan, sebuah survei pada Februari 2018 menunjukkan adanya perbaikan kesempatan bekerja dengan makin terbukanya lapangan pekerjaan, dimana pada tahun 2018 lapangan kerja meningkat 2,5 juta dibandingkan tahun 2017. Sementara itu, jumlah pengangguran turun sekitar 135.000 sehingga angka pengangguran terbuka menjadi 5,13 persen. Namun, melihat pergerakan pada Agustus 2018, ada kemungkinan tingkat pengangguran terbuka akan meningkat.

Badan Pusat Statistik (BPS) merilis jumlah pengangguran pada Agustus 2018 bertambah 130 ribu jiwa menjadi 7 juta jiwa dibanding posisi Februari 2018 sebanyak 6,87 juta jiwa. Demikian pula jika dibanding posisi Agustus 2017 jumlah pengangguran bertambah 40 ribu jiwa. Jumlah pekerja yang berkurang lebih cepat (3,06 juta jiwa) dibanding berkurangnya jumlah angkatan kerja (2,93 juta jiwa) memicu kenaikan pengangguran pada semester kedua tahun ini, sehingga tingkat pengangguran pada semester kedua 2018 meningkat menjadi 
5,34\% dari total angkatan kerja sebanyak 124 juta jiwa.

Angka pengangguran tersebut lebih tinggi dibanding pada semester pertama sebesar $5,13 \%$ dengan angkatan kerja mencapai 133,94 juta jiwa. Namun lebih rendah dari posisi semester kedua 2017 yang mencapai 5,5\% dengan angkatan kerja sebanyak 128,06 juta jiwa. Hal ini disebabkan kondisi musiman karena bukan musim panen dan dampak pelemahan rupiah

\section{METODE PENELITIAN}

Metode yang digunakan dalam penelitian ini adalah metode penelitian kuantitatif yaitu penelitian ilmiah yang sistematis terhadap bagian-bagian dan fenomena-fenomena serta hubungannya. Tujuan penelitian kuantitatif adalah mengembangkan dan menggunakan model-model matematis, teori-teori dan/atau hipotesis yang berkaitan dengan fenomena alam.

Penelitian ini dilaksanakan di Fakultas Keguruan dan Ilmu Pendidikan Universitas HKBP Nommensen Medan. Penelitian ini dilakukan pada semester genap tahun pembelajaran 2018/2019.

Sampel dalam penelitian ini ditentukan dengan menggunakan rumus slovin. Jumlah sampel sebanyak 195 orang mahasiswa/I FKIP Universitas HKBP Nommensen Medan

\section{HASIL PENELITIAN}

Pengaruh antara Pembelajaran Mata Kuliah Kewirausahaan terhadap minat berwirausaha mahasiswa FKIP Nommensen Medan Tahun Ajaran 2018/2019.

Berdasarkan pengolahan data analisa regeresi linear sederhana dengan bantuan program SPSS, diperoleh hasil seperti dimuat pada tabel di bawah ini.

\section{Tabel 4.64}

\section{Koefisien Regresi Pembelajaran Mata Kuliah Kewirausahaan Terhadap Minat Beriwirausaha Mahasiswa FKIP Nommensen Medan}

\begin{tabular}{|c|c|c|c|c|c|c|}
\hline \multicolumn{7}{|c|}{ Coefficients $^{a}$} \\
\hline \multirow{2}{*}{\multicolumn{2}{|c|}{ Model }} & \multicolumn{2}{|c|}{$\begin{array}{l}\text { Unstandardized } \\
\text { Coefficients }\end{array}$} & $\begin{array}{l}\text { Standar } \\
\text { dized }\end{array}$ & \multirow[t]{2}{*}{$\mathrm{t}$} & \multirow[t]{2}{*}{ Sig. } \\
\hline & & $B$ & $\begin{array}{l}\text { Std. } \\
\text { Error }\end{array}$ & Beta & & \\
\hline & (Constant) & 12.399 & 6.418 & & 1.932 & .055 \\
\hline 1 & $\begin{array}{l}\text { Pembelajaran } \\
\text { Mata Kuliah } \\
\text { Kewirausahaan }\end{array}$ & 1.063 & .104 & .592 & $\begin{array}{r}10.21 \\
1\end{array}$ & .000 \\
\hline
\end{tabular}

a. Dependent Variable: Minat Berwirausaha

Dari tabel di atas dapat dilihat bahwa nilai konstanta untuk variable pembelajaran mata kuliah kewirausahaan adalah 12,399, sedangkan hasil nilai koefisien pembelajaran mata kuliah kewirausahaan adalah 1,063. Dengan demikian dapat dibuat persamaan regresi linear dengan mengacu pada rumus $\hat{Y}$ $=\mathrm{a}+\mathrm{b} 1 . \mathrm{X} 1$, sebagai berikut :

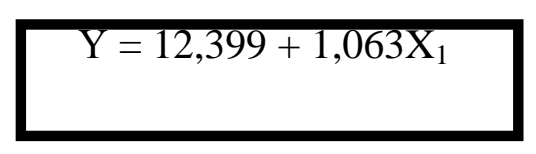

Dimana : $\hat{Y}$ adalah minat berwirausaha, dan X1 adalah pembelajaran mata kuliah kewirausahaan . arti yang dimaksud di dalam persamaan regresi linear tersebut adalah :

- Nilai konstanta sebesar 12,399 menyatakan bahwa jika nilai X1 = 0 atau variable pembelajaran mata kuliah kewirausahaan tidak ada maka nilai variable minat berwirausaha mahasiswa adalah sebsar 12,399

- Koefisien regresi variable pembelajaran mata kuliah kewirausahaan 1,063, maksudnya adalah bahwa setiap penambahan 1 (satu) poin variable pembelajaran mata kuliah kewirausahaan, maka hal itu akan meningkatkan minat berwirausaha mahasiswa sebesar 1,063 kali.

Intepretasi dari persamaan di atas bahwa koefisien regresi variable pembelajaran mata kuliah kewirausahaan (X1) memiliki tanda postif $(1,063)$, yaitu maksudnya adalah implikasi bahwa pembelajaran mata kuliah kewirausahaan searah dengan variable minat berwirausaha mahasiswa, dengan kata lain bahwa variable pembelajaran mata kuliah kewirausahaan mempunyai pengaruh positif terhadap minat berwirausaha. 
Pengujian hipotesis dilakukan dengan uji $\mathrm{t}$ yang kegunaannya adalah untuk mengetahui diterima atau ditolaknya hipotesis, dengan ketentuan seperti yang telah dijelaskan sebelumnya.

\section{- Uji-t}

Untuk melakukan uji-t digunakan tabel coefficient, seperti yang telah tercantum pada tabel 4.64 di atas. Uji-t dilakukan untuk mengetahui apakah variable bebas (pembelajaran mata kuliah kewirausahaan) terhadap vriabel terikat (minat berwirausaha mahasiswa) mempunyai pengaruh yang nyata atau tidak. Berdasarkan tabel di atas diperoleh t-hitung sebesar 10,211 pada tingkat sig sebesar 0,000 . Hal ini berarti nilai t-hitung sebesar 10,221 pada level probabilitas (kepercayaan) 0,05\% (95\%) ttabel dihitung dengan mencari nilai degree of freedom ( $\mathrm{df}$ ) dengan rumus $\mathrm{df}=\mathrm{n}-2$, dimana $\mathrm{k}$ adalah jumlah variable penelitian dan $\mathrm{n}$ adalah banyaknya responden, df $=195-2=$ 193. Taraf signifikansinya adalah 5\% (karena dua sisi, maka signifikansinya 0,025) maka besarnya nilai t-tabel adalah 1.97233 . Hal ini berarti Ho ditolak dan $\mathrm{H}_{1}$ diterima. Kebermaknaan ini mengandung implikasi bahawa pembelajaran mata kuliah kewirausahaan berpengaruh terhadap minat berwirausaha mahasiswa FKIP Nommensen Medan

\section{Pengaruh antara Praktik Kewirausahaan terhadap minat berwirausaha mahasiswa FKIP Nommensen Medan Tahun Ajaran 2018/2019.}

Berdasarkan pengolahan data analisa regeresi linear sederhana dengan bantuan program SPSS, diperoleh hasil seperti dimuat pada tabel di bawah ini.

\section{Tabel 4.65}

\section{Koefisien Regresi Prakti Kewirausahaan} Terhadap Minat Beriwirausaha Mahasiswa FKIP Nommensen Medan

\begin{tabular}{|c|c|c|c|c|c|}
\hline \multicolumn{6}{|c|}{ Coefficients $^{a}$} \\
\hline \multirow[t]{2}{*}{ Model } & \multicolumn{2}{|c|}{$\begin{array}{l}\text { Unstandardized } \\
\text { Coefficients }\end{array}$} & \multirow{2}{*}{$\begin{array}{c}\begin{array}{c}\text { Standardi } \\
\text { zed } \\
\text { Coefficie } \\
\text { nts }\end{array} \\
\text { Beta }\end{array}$} & \multirow[t]{2}{*}{$\mathrm{T}$} & \multirow[t]{2}{*}{ Sig. } \\
\hline & $B$ & $\begin{array}{l}\text { Std. } \\
\text { Error }\end{array}$ & & & \\
\hline (Constant) & 52.814 & 3.419 & & 15.448 & .000 \\
\hline $\begin{array}{l}\text { Praktik } \\
\text { Kewirausahaan }\end{array}$ & .628 & .085 & .470 & 7.391 & .000 \\
\hline
\end{tabular}

a. Dependent Variable: Minat Berwirausaha

Dari tabel di atas dapat dilihat bahwa nilai konstanta untuk variable pembelajaran mata kuliah kewirausahaan adalah 52,814, sedangkan hasil nilai koefisien pembelajaran mata kuliah kewirausahaan adalah 0,628. Dengan demikian dapat dibuat persamaan regresi linear dengan mengacu pada rumus $\hat{Y}=a+b 1 . X 2$, sebagai berikut :

$$
\hat{\mathrm{Y}}=52,814+0,628 \mathrm{X}_{2}
$$

Dimana : $Y$ adalah minat berwirausaha, dan $\mathrm{X}_{2}$ adalah praktik kewirausahaan . arti yang dimaksud di dalam persamaan regresi linear tersebut adalah :

- Nilai konstanta sebesar 52,814 menyatakan bahwa jika nilai $\mathrm{X}_{2}=0$ atau variable pembelajaran mata kuliah kewirausahaan tidak ada maka nilai variable minat berwirausaha mahasiswa adalah sebsar 52,814

Koefisien regresi variable pembelajaran mata kuliah kewirausahaan 0,628, maksudnya adalah bahwa setiap penambahan 1 (satu) poin variable pembelajaran mata kuliah kewirausahaan, maka hal itu akan meningkatkan minat berwirausaha mahasiswa sebesar 0,628 kali.

Intepretasi dari persamaan di atas bahwa koefisien regresi variable praktik kewirausahaan $\left(\mathrm{X}_{2}\right)$ memiliki tanda postif $(0,628)$, yaitu maksudnya adalah implikasi bahwa praktik kewirausahaan searah dengan variable minat berwirausaha mahasiswa, dengan kata lain bahwa variable praktik kewirausahaan mempunyai pengaruh positif terhadap minat berwirausaha.

\section{- Uji-t}

Untuk melakukan uji-t digunakan tabel coefficient, seperti yang telah tercantum pada tabel 4.65 di atas. Uji-t dilakukan untuk mengetahui apakah variable bebas (pembelajaran mata kuliah kewirausahaan) terhadap vriabel terikat (minat berwirausaha mahasiswa) mempunyai pengaruh yang nyata atau tidak. Berdasarkan tabel di atas diperoleh t-hitung sebesar 7,391 pada tingkat sig sebesar 0,000 . Hal ini berarti nilai t-hitung sebesar 7,391 pada level probabilitas (kepercayaan) $\quad 0,05 \% \quad(95 \%) \quad$ t-tabel dihitung dengan mencari nilai degree of 
freedom (df) dengan rumus $\mathrm{df}=\mathrm{n}-2$, dimana $\mathrm{k}$ adalah jumlah variable penelitian dan $\mathrm{n}$ adalah banyaknya responden, $\mathrm{df}=195-2=193$. Taraf signifikansinya adalah 5\% (karena dua sisi, maka signifikansinya 0,025 ) maka besarnya nilai t-tabel adalah 1.97233

Dari hasil perhitungan di atas diketahui bahwa nilai t-hitung sebesar 7,391 > t-tabel $(\mathbf{7 , 3 9 1 > 1 , 9 7 2 3 3})$ dan sig < $0,05(\mathbf{0 , 0 0}<\mathbf{0 , 0 5})$. Hal ini berarti Ho ditolak dan $\mathrm{H}_{1}$ diterima. Kebermaknaan ini mengandung implikasi bahawa praktik kewirausahaan berpengaruh terhadap minat berwirausaha mahasiswa FKIP Nommensen Medan

$\begin{array}{lcr}\text { Analisis Regresi } & \text { Berganda : } & \text { Pengaruh } \\ \text { Pembelajaran } & \text { Mata } & \text { Kuliah } \\ \text { Kewirausahaan } & \text { dan } & \text { Praktik } \\ \text { Kewirausahaan } & \text { terhadap } & \text { Minat } \\ \text { Berwirausaha } & \text { Mahasiswa } & \text { FKIP } \\ \text { Nommensen Medan } & \text { Tahun } & \text { Ajaran } \\ \text { 2018/2019. } & & \end{array}$

Untuk melihat pengaruh pembelajaran mata kuliah kewirausahaan dan praktik kewirausahaan secara bersama-sama terhadap minat berwirausaha, digunakan analisa regresi berganda dengan bantuan program SPSS hasil seperti termuat pada tabel berikut ini Tabel 4.66

Hasil Perhitungan Regresi Linear Berganda Pengaruh Pembelajaran Mata Kuliah Kewirausahaan dan Praktik Kewirausahaan terhadap Minat Berwirausaha Mahasiswa FKIP Nommensen Medan Coefficients $^{a}$

\begin{tabular}{|l|r|r|r|r|r|}
\hline Model & \multicolumn{2}{|c|}{$\begin{array}{c}\text { Unstandardized } \\
\text { Coefficients }\end{array}$} & $\begin{array}{c}\text { Stand } \\
\text { ardize } \\
\mathrm{d} \\
\text { Coeffi } \\
\text { cients }\end{array}$ & $\mathrm{t}$ & Sig. \\
\cline { 2 - 4 } & $\mathrm{B}$ & $\begin{array}{c}\text { Std. } \\
\text { Error }\end{array}$ & Beta & & \\
\hline & $\begin{array}{r}13.24 \\
\text { (Constant) }\end{array}$ & 6.253 & & 2.117 & .036 \\
$\begin{array}{l}\text { Pembelajaran Mata } \\
\text { Kuliah Kewirausahaan }\end{array}$ & .855 & .118 & .477 & 7.241 & .000 \\
$\begin{array}{l}\text { Praktik } \\
\text { Kewirausahaan }\end{array}$ & .300 & .088 & .224 & 3.409 & .001 \\
\hline
\end{tabular}

a. Dependent Variable: Minat Berwirausaha

Dari data yang terlihat pada tabel diatas, dapat diketahui bahwa nulai konstanta regresi linear berganda 13,240 dengan nilai koefisien regresi variable pembelajaran kewirausahaan $\mathbf{0 , 8 5 5}$, nilai koefisien regresi praktik kewirausahaan $\mathbf{0 , 3 0 0}$. maka dengan mengacu pada rumus persamaan regresi linear berganda $\hat{\mathrm{Y}}=\mathrm{a}+\mathrm{b} 1 . \mathrm{X} 1+\mathrm{b} 2 . \mathrm{X} 2$, dapat dibentuk persamaan regresi linear berganda sebagai berikut :

$$
\hat{Y}=13,240+0,855 . X_{1}+0,300 \cdot X_{2}
$$

Kebermaknaan dari persamaan regresi linear berganda di atas mengandung implikasi : Konstanta 13,240 mengandung arti apabila variable pembelajaran mata kuliah kewirausahaan, dan praktik kewirausahaan tidak ada maka $\left(\mathrm{X}_{1}, \mathrm{X}_{2}=0\right)$ maka minat berwirausaha mahasiswa berada pada angka 13,240.

Koefisen regresi $X_{1}$ (Pembelajaran Mata Kuliah Kewirausahaan )0,855 mengandung arti bahwa setiap penambahan satu point variable pembelajaran mata kuliah kewirausahaan akan meningkatkan minat berwirausaha mahasiswa 0,855 kali.

$$
\begin{array}{lll}
\text { Koefisien } & \mathrm{X}_{2} & \text { (Praktik }
\end{array}
$$

kewirausahaan)0,300 mengandung arti bahwa setiap penambahan satu poin variable praktik kewirausahaan akan meningkatkan minat berwirausaha mahasiswa sebesar 0,300 kali.

Uji-F

Dengan bantuan tabel Anova hasil dari pengolahan data dengan SPSS diperoleh data sebagai berikut :

Tabel 4.67

Hasil uji F Pembelajaran Kewirausahaan, dan Praktik Kewirausahaan secara

\begin{tabular}{|c|c|c|c|c|c|}
\hline Model & $\begin{array}{c}\text { Sum of } \\
\text { Squares }\end{array}$ & $\overline{D f}$ & Mean Square & $\mathrm{F}$ & Sig. \\
\hline $\begin{array}{l}\text { Regression } \\
\text { Residual } \\
\text { Total }\end{array}$ & $\begin{array}{r}6808.054 \\
10747.864 \\
17555.918\end{array}$ & $\begin{array}{r}2 \\
192 \\
194\end{array}$ & $\begin{array}{r}3404.027 \\
55.978\end{array}$ & 60.810 & $.000^{\mathrm{D}}$ \\
\hline
\end{tabular}
bersama-sama

Kewirausahaan

Berdasarkan data tabel di atas diperoleh Fhitung sebesar 60,810 dan sig 0,000. F-tabel pada taraf $\alpha=0.05$, df $1=$ (jumlah variable independen $=2)$ dan df2 (n-k-1 = 195-2-1 = 192, maka nilai F-tabel $=1,97240$. Hal ini berarti F-hitung > F-tabel $(\mathbf{6 0 , 8 1 0}>\mathbf{1 , 9 7 2 4 0})$ dan sig < 0,05 $(0,000<0,05)$, maka hipotesis dapat diterima. Dalam hal ini dapat dikatakan variable pembelajaran mata kuliah kewirausahaan dan praktik kewirausahaan secara berasama-sama berpengaruh secara 
postif terhadap minat berwirausaha mahasiswa, sehingga ketiga variable independen tersebut dapat digunakan utnuk mengestimasi atau memprediksi variable minat berwirausaha mahasiswa.

\section{Koefisien Determinasi}

Uji koefisien determinasi digunakan utnuk mengukur ketapatan dari model analisis yang dibuat. Nilai koefisien determinasi merupakan alat untuk mengukur besarnya sumbangan dari variable bebas yang diteliti terhadap variable terikat. adapun hasil koefisien determinasi masing-masing variable sebagai berikut :

Tabel 4.68

Hasil uji Koefisien Determinasi

\begin{tabular}{|l|r|r|r|r|}
\hline Model & $\mathrm{R}$ & $\mathrm{R}$ Square & $\begin{array}{c}\text { Adjusted R } \\
\text { Square }\end{array}$ & $\begin{array}{c}\text { Std. Error } \\
\text { of the } \\
\text { Estimate }\end{array}$ \\
\hline 1 & $.623^{\mathrm{a}}$ &. $\mathbf{3 8 8}$ & .381 & 7.482 \\
\hline
\end{tabular}
a. Predictors: (Constant), Praktik Kewirausahaan ,
Pembelajaran Mata Kuliah Kewirausahaan

Dari tabel model summary di atas dapat diketahui bahwa nilai $\mathrm{R}$ adalah 0,654, sedangkan nilai $\mathrm{R}^{2}$ sebesar 0,388 . Oleh Karena uji koefisien determinasi berganda ini diperoleh dari perhitungan regresi linear berganda, maka koefisen determinasi sebesar $\mathbf{0 , 3 8 8}$ atau $\mathrm{R}^{2} \mathrm{x} 100 \%$ sebesar $\mathbf{3 8 , 8 0 \%}$. Kebermaknaan dari nilai tersebut memiliki implikasi bahwa variable pembelajaran mata kuliah kewirausahaan dan praktik kewirausahaan berpengaruh terhadap minat berwirausaha mahasiswa FKIP Nommensen Medan Tahun Ajaran 2018/2019 sebesar $38,80 \%$, dan sisanya 61,20 dipengaruhi oleh variable-variabel lain di luar model yag dimasukkan dalam penelitian ini.

\section{Pembahasan}

\section{Pengaruh Pembelajaran Mata Kuliah Kewirausahaan terhadap Minat Berwirausaha Mahasiswa FKIP Universitas HKBP Nommensen Medan Tahun Pelajaran 2018/2019.}

Hasil analisis menggunakan regresi linier sederhana menunjukkan pembelajaran mata kuliah kewirausahaan berpengaruh positif dan signifikan terhadap minat berwirausaha mahasiswa. Hasil pengujian regresi inier sederhana mendapatkan koefisien korelasi $\left(\mathrm{rx}_{1} \mathrm{y}\right)$ sebesar $(10,221>1,97233)$ dan sig $<0,05(0,00<$
$0,05)$ atau probabilotas di bawah $\alpha=5 \%$. Hal ini dapat disimpulkan bahwa terdapat pengaruh positif dan signifikan pembelajaran mata kuliah kewirausahaan terhadap minat berwirausaha mahasiswa FKIP Universitas HKBP Nommensen Medan Tahun Pelajaran 2018/2019

Hasil penelitian sesuai dengam kajian teori dan penelitian yang relevan menurut Daryanto (2012:2) kewirausahaan adalah kemampuan untuk menciptakan sesuatu yang baru dan berbeda melalui berpikir kreatif dan bertindak inovatif untuk menciptakan peluang. Pembelajaran kewirausahaan adalah salah satu jalan terbaik untuk meningkatkan minat berwirausaha dan meneguhkan keyakinan para siswa dapat mengaktualisasikan sikap dan perilaku wirausaha, menerapkan jiwa kepemimpinan, merencanakan usaha kecil, dan mengelola usaha kecil. Dengan hal tersebut diharapkan dapat menciptakan nilai tambah atau penghasilan, menciptakan lapangan pekerjaan dan berguna bagi orang lain. Hal ini sesuai dengan penelitian yang dilakukan oleh Ahmad fauzan Yuliarto 2017 dengan judul "Pengaruh pembelajaran kewirausahaan dan praktik kewirausahaan terhadap minat berwirausaha siswa kelas XI Akuntansi SMK Negeri 1 Klaten Tahun Pelajaran 2016/2017" Berdasarkan hasil penelitian diperoleh kesimpulan (1) terdapat pengaruh positif dan signifikan pembelajaran kewirausahaan terhadap minat berwirausaha siswa kelas XI Akuntansi SMK Negeri 1 Klaten Tahun pelajaran 2016/2017 dengan koefisien korelasi (rx1y) sebesar $0,435>r_{\text {tabel }} 0,159$ dengan nilai siginifikasi $t$ sebesar 0,000 dan persamaan garis linier $\mathrm{Y}=0,415 \mathrm{X}_{1}+45,045$.(2) terdapat pengaruh positif dan signifikan praktik kewirausahaan terhadap minat berwirausaha siswa kelas XI akuntansi SMK Negeri 1 Klaten tahun Pelajaran 2016/2017 dengan koefisien korelasi (rx2y) sebesar 0,632>r $\mathrm{r}_{\text {tabel }} 0,159$, koefisien determinasi $\left(\mathrm{r}^{2} \mathrm{x} 2 \mathrm{y}\right)$ sebesar 0,399, nilai $t_{\text {hitung }}$ sebesar $8,389>t_{\text {tabel }} 1,659$, dengan nilai signifikansi $\mathrm{t}$ sebasar 0,000 dan persamaan garis linier $\mathrm{Y}=0,906 \mathrm{X}_{2}+37,760$.

\section{Pengaruh Praktik Kewirausahaan} terhadap Minat Berwirausaha Mahasiswa 
FKIP Universitas HKBP Nommensen Medan Tahun Pelajaran 2018/2019

Hasil analisis regresi linier sederhana menunjukkan prakti kewirausahaan berpengatuh positif dan signifikan terhadap minat berwirausaha. Hasil pengujian regresi linier sederhana mendapatkan koefisien korelasi $\left(\mathrm{rx}_{2} \mathrm{y}\right)$ sebesar 7,391 $>$ t-tabel $\mathbf{( 7 , 3 9 1 > 1 , 9 7 2 3 3 )}$ dan sig $<0,05(\mathbf{0 , 0 0}<\mathbf{0 , 0 5})$ dengan nilai signifikansi t sebesar 0,000 atau probabilitas di bawah $\alpha=5 \%$. Hal ini dapat disimpulkan bahwa terdapat pengaruh positif dan signifikan praktik kewirausahaan terhadap minat berwirausaha mahasiswa FKIP Universitas HKBP Nommensen Medan Tahun Pelajaran 2018/2019.

Hasil penelitian sesuai dengan kajian teori dan penelitian yang relevan. Menurut Riyanti (2003:67), faktor-faktor yang mempengaruhi minat adalah pengalaman dan pendidikan. Untuk membentuk minat berwirausaha dimulai dengan tahapan pemahaman teoru, studi kasus, motivasi dan pemberian pengalaman. Pemberian pengalaman berupa praktik kewirausahaan diharapkan memberikan mahasiswa bekal keterampilan yang cukup dalam memulai sebuah usaha kecil sehingga akan meningkatkan minat berwirausaha mahasiswa. Hal ini sesuai dengan penelitian yang dilakukan oleh Apriliana Eka Safitri Nugroho 2013 dengan judul "Kontribusi Prestasi Praktik Kewirausahaan terhadap minat berwirausaha siswa kelas XII busana butik SMK Negeri 1 Wonosari" Terdapat pengaruh positif dan signifikan prestasi praktik kewirausahaan terhadap minat berwirausaha, ditunjukkan koefisien determinasi $\left(r^{2} \mathrm{x} 1, \mathrm{y}\right)$ sebesar 0,213 dan $\mathrm{t}_{\text {hitung }}$ sebesar 3,896>t $t_{\text {tabel }} 2,000$.

\section{Pengaruh Pembelajaran Mata Kuliah} Kewirausahaan dan Praktik Kewirausahaan secara bersama-sama terhadap Minat Berwirausaha Mahasiswa FKIP Universitas HKBP Nommensen Medan Tahun Ajaran 2018/2019.

Hasil analisis menggunakan regresi ganda menunjukkan bahwa secara bersamasama pembelajaran kewirausahaan dan praktik kewirausahaan berpengaruh positif dan signifikan terhadap minat beriwirausaha. Hasil uji $\mathrm{F}$ mendapatkan nilai $\mathrm{F}_{\text {hitung }}$ sebesar
60,810> $\mathrm{F}_{\text {tabel }} 1,97240$ dengan nilai signifikansi $0,000<0,05$. Nilai ini signifikan secara statistic, karena tingkat signifikannya di bawah 0,05 yang berarti bahwa terdapat pengaruh postif dan signifikan pembelajaran mata kuliah kewirausahaan dan praktik kewirausahaan secara bersama-sama terhadap minat berwirausaha mahasiswa FKIP Universitas HKBP Nommensen Medan Tahun Pelajaran 2018/2019. Kemudian hasil pengujian regresi ganda menunjukkan bahwa koefisien korelasi sebesar 0,623 dan koefisien determinasi $=0,388$. Jadi dapat disimpulkan bahwa $38,8 \%$ minat berwirausaha dipengaruhi oleh pembelajaran kewirausahaan dan praktik kewirausahaan. Sedangkan sisanya sebesar $61,2 \%$ dipengaruhi variable lain yang tidak diteliti dalam penelitian ini.

Dalam kajian teori yang dikemukakan oleh Maman S (2006:46) menyatakan bahwa ada 8 faktor yang dapat menjadi pendorong pertumbuhan minat wirausaha di era modern ini yaotu pendapat bahwa wirausaha adalah seoarang pahlawan; pendidikan kewirausahaan; media pelatihan kewirausahaan; faktor ekonomi dan kependudukan; pergeseran dari ekonomi industry ke ekonomi jasa; kemajuan teknologi; gaya hidup bebas; dan terbukanya peluang bisnis internasional. Pembelajaran mata kuliah kewirausahaan dan praktik kewirausahaan merupakan bagian dari faktor pendorong pertumbuhan minat kewirausahaan berupa pendidikan kewirausahaan. Penelitian yang dilakukan saat ini semakin menguatkan dengan adanya kajian teori yang mendukung. Oleh Karen itu, pembelajaran mata kuliah kewirausahaan dan praktik kewirausahaan secara bersamasama memiliki pengaruh postif dan signifikan terhadap minat berwirausaha mahasiswa FKIP Universitas HKBP Nommensen Medan Tahun Pelajaran 2018/2019

\section{KESIMPULAN}

Berdasarkan data yang diperoleh dari hasil analisis yang dilakukan maka dapat ditarik kesimpulan sebagai berikut :

1. Terdapat pengaruh positif dan signifikan pembelajaran mata kuliah kewirausahaan terhadap minat berwirausaha mahasiswa 
FKIP Universitas HKBP Nommensen Medan Tahun Pelajaran 2018/2019. Hal ini ditunjukkan dari hasil uji regresi sederhana dimana diketahui bahwa nilai thitung sebesar 10,221 > t-tabel $(\mathbf{1 0 , 2 2 1}>\mathbf{1 , 9 7 2 3 3})$ dan sig $<0,05(\mathbf{0 , 0 0}<$ $\mathbf{0 , 0 5})$, dan persamaan garis regresi linier sederhana $\mathrm{Y}=12,399+1,063 \mathrm{X}_{1}$

2. Terdapat pengaruh positif dan signifikan praktik kewirausahaan terhadap minat berwirausaha mahasiswa FKIP Universitas HKBP Nommensen Medan Tahun Ajaran 2018/2019. Hal ini ditunjukkan dengan hasil pengujian regresi sederhana diketahui bahwa nilai thitung sebesar 7,391>t-tabel $(\mathbf{7 , 3 9 1}>\mathbf{1 , 9 7 2 3 3})$ dan sig $<0,05(\mathbf{0 , 0 0}<$ $\mathbf{0 , 0 5}$ ) dan persamaan garis linier sederhana $\mathrm{Y}=52,814+0,628 \mathrm{X}_{2}$.

3. Terdapat pengaruh positif dan signifikan Pembelajaran Mata kuliah kewirausahaan dan praktik kewirausahaan secara bersama-sama terhadap minat berwirausaha mahasiswa FKIP Universitas HKBP Nommensen Medan Tahun Perlajaran 2018/2019. Hal ini ditunjukkan dengan hasil pengujian regresi berganda diperoleh F-hitung sebesar 60,810 dan sig 0,000. F-tabel pada taraf $\alpha=0.05$, df $1=$ (jumlah variable independen = 2) dan df2 (n-k-1 = 195-2-1 $=192$, maka nilai $\mathrm{F}$-tabel $=1,97240$. Hal ini berarti F-hitung > F-tabel $(\mathbf{6 0 , 8 1 0}>\mathbf{1 , 9 7 2 4 0})$ dan sig $<0,05(0,000<$ $0,05)$, dan koefisien determinasi $R^{2} y(1,2)$ sebesar 0,388. Hasil tersebut menunjukkan $38,8 \%$ minat berwirausaha dipengaruhi oleh pembelajaran kewirausahaan dan praktik kewirausahaan sedangkan sisanya sebesar 61,2\% dipengaruhi variable lain yang tidak diteliti dalam penelitian ini. Persamaan regresi ganda $\mathrm{Y}=13,240+0,855 . \mathrm{X}_{1}+$ $0,300 . X_{2}$

\section{UCAPAN TERIMAKASIH}

Peneliti mengucapkan terimakasih kepada Universitas HKBP Nommensen Medan yang telah memberikan kesempatan untuk melakukan penelitian di lingkungan Universitas Nommensen khususnya di Fakultas Keguruan dan Ilmu Pendidikan. Tidak lupa pula peneliti ingin mengucapkan terimakasih kepada LPPM Univeristas HKBP Nommensen Medan yang telah memberikan dukungan berupa pendanaan sehingga penelitian ini bisa terlaksana

\section{DAFTAR PUSTAKA}

Ahmad Fauzan Yuliarto. (2017). Pengaruh Pembelajaran Kewirausahaan dan Praktik Kewirausahaan Terhadap Minat Berwirausaha Siswa Kelas XI Akuntansi SMK negeri Klaten Tahun Pelajaran 2016/2017.Skripsi. Yogyakarta. Universitas Negeri Yogyakarta.

Apriliana Eka Safitri Nugroho. (2013). Kontribusi Prestasi Praktik Kewirausahaan Terhadap Minat Berwirausaha Siswa Kelas XII Busana Butik SMK Negeri 1 Wonosari. Skripsi. Yogyakarta: Universitas Negeri Yogyakarta.

Ayu Noviana Hanum. (2013). Pengaruh Mata kuliah Kewirausahaan Terhadap Minat Mahasiswa Menjadi Wirausaha (Studi kasus pada Universitas Muhammadiyah Semarang). Skripsi. Semarang :Universitas Muhammadiyah Semarang

Ating Tedjasutisna. (2007). Memahami Kewirausahaan SMK Tingkat I. Bandung : ARMICO

Basrowi. (2011). Kewirausahaan untuk Perguruan Tinggi. Bogor: Ghalia Indonesia.

Buchari Alma. (2013). Kewirausahaan Untuk Mahasiswa dan Umum. Bandung: Alfabeta.

Eddy Soertyanto S. (2009). Enterpreneurship Menjadi Pebisnis Ulung. Jakarta: PT. ELEX Media Komputindo

Eman Suherman. (2010). Desain Pembelajaran Kewirausahaan. Bandung: Alfabeta.

Hendro. (2011). Dasar-Dasar Kewirausahaan. Jakarta: Erlangga.

Maman S. (2006). Pendidikan Wiraswasta. Jakarta: Sinar Grafika Offset.

Moekijat. (2000). Manajemen Penjualan. Yogyakarta: Penerbit Manajemen Informatika UGM

Muhibbin Syah. (2011). Psikologi Belajar. Jakarta: Rajawali Pers. 
Riyanti. (2003). Kewirausahaan Dari Sudut Pandang Psikologi Kepribadian. Jakarta: Grasindo

Rusdiana. (2014). Kewirausahaan Teori dan Praktik. Bandung: CV Pusaka Setia

Sugiyono. 2007. Metode Penelitian Pendidikan Pendekatan Kuantitatif, Kualitatif, dan R\&D. Bandung : Alfabeta

Suharsimi Arikunto. 2010. Prosedur Penelitian Suatu Pendekatan Praktik. Jakarta : PT. Rineka Cipta.

Suryana. (2006). Kewirausahaan: Pedoman, Praktis, Kiat dan Proses Menuju Sukses. Jakarta: Salemba Empat.

Winkel. (2004). Psikologi Pengajaran. Jakarta: PT Grasfindo.

Zainudin, M. (2005). Pedoman Pembelajaran Praktikum di Laboratorium. Yogyakarta

https://www.republika.co.id/berita/ekonom i/korporasi/18/10/18/pgsax3383enggartiasto-tingkat-kewirausahaandi-indonesia-rendah

https://nasional.sindonews.com/read/13073 12/144/mahasiswa-berpotensi-jadientrepreneur-di-era-40-1526785449

https://databoks.katadata.co.id/datapublish /2018/11/06/bertambah-130-ribujiwapengangguran-agustus-2018menjadi-534 